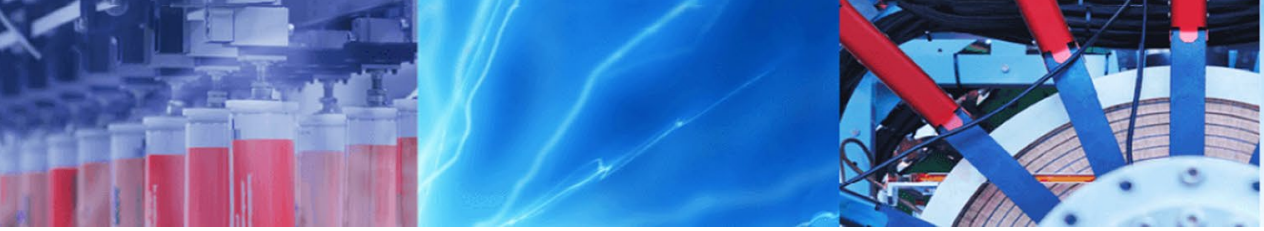

Research Article

\title{
Preparation of a steroid-oxazole-1,2'-[1,3]oxazete] derivative: biological and theoretical evaluation of its interaction with a kinase protein (CK2)
}

\author{
Figueroa-Valverde Lauro ${ }^{1}$ - Diaz-Cedillo Francisco ${ }^{2} \cdot$ Rosas-Nexticapa Marcela $^{3} \cdot$ Mateu-Armand Virginia $^{3}$. \\ Pool Gómez Eduardo ${ }^{1}$ - Lopez-Ramos Maria ${ }^{1} \cdot$ Hau-Heredia Lenin ${ }^{1}$ - Alfonso-Jimenez Alondra ${ }^{1}$ Cabrera-Tuz Jhair ${ }^{1}$
}

(c) Springer Nature Switzerland AG 2019

\begin{abstract}
The aim of this study was synthesizing a steroid-oxazole-oxazete derivative (4) to evaluate their biological activity in vitro. The first stage was achieved by the preparation of a steroid-oxazole-1,2'-[1,3]oxazete] derivative using a series of reactions such as; (1) addition; (2) nitration and (3) cyclization. Then, the biological activity of steroid analog against infarct area was evaluated on an ischemia/reperfusion model using quinalizarin as a control. In addition, the interaction of steroid derivative with kinase protein (CK2) was evaluated using a docking model. The results showed a decrease infarct area $(0.001 \mathrm{nM}]$ in a similar form that quinalizarin. In addition, the theoretical analysis suggests that steroid derivative could interact with some aminoacid residues $\left(\mathrm{Gln}_{86}, \mathrm{Lys}_{96}, \mathrm{Leu}_{97}, \mathrm{Leu}_{98}\right)$ of $3 \mathrm{FL} 5$ protein surface. All these data indicate that steroid derivative can decrease the infarct area via CK2 inhibition.
\end{abstract}

Keywords Steroid $\cdot$ Infarct $\cdot$ Ischemia $\cdot$ Kinase protein

\section{Introduction}

There are several studies which indicate that myocardial infarction is a major cause of health worldwide; this clinical pathology can be conditioned by the cardiac myocyte cell death caused by prolonged myocardial ischemia [1]. Some data suggest that restoration of blood flow could limit cardiac necrosis [2]; however, the effects of reperfusion may be associated with tissue damage $[3,4]$. Here, it should be noted that several vasoactive substances can be produced through an ischemia/reperfusion injury, such as the generation of reactive oxygen species and protein phosphorylation $[5,6]$. For example, casein kinase (CK2) can induce phosphorylation of some biomolecules [7-11] such as CAMP-dependent protein kinase [12], NF-KB (nuclear factor kappa B), STAT-1 (signal transducer and activator of transcription-1) [13] and CREB (CAMP response element-binding) [14], which may are been associated to ischemia/reperfusion injury [15-17]. It is noteworthy that to characterize the molecular mechanism involved in the effect exerted by CK2 in different tissues, several studies have been carried out using some drugs such as benzimidazole [18], TBB (4,5,6,7-tetrabromo-2-azabenzimidazole) [19], heparin [20], emodin [21], quinalizarin [22], which can modify their biological activity. All these data suggest that some drugs can inhibit the effect of CK2; however, the interaction of some drugs with CK2 is very confusing, perhaps this phenomenon could be due to; (1) differences in the chemical structure of each drug; or (2) to different methods used in each experiment. Therefore, the aim of

$\triangle$ Figueroa-Valverde Lauro, Ifiguero@uacam.mx; $\triangle$ Rosas-Nexticapa Marcela, rosasnm@yahoo.com | 1 Laboratory of Pharmaco-Chemistry, Faculty of Chemical Biological Sciences, University Autonomous of Campeche, Av. Agustín Melgar s/n, Col Buenavista, C.P. 24039 Campeche, CAM, Mexico. ${ }^{2}$ Escuela Nacional de Ciencias Biológicas del Instituto Politécnico Nacional, Prol. Carpio y Plan de Ayala s/n Col. Santo Tomas, C.P. 11340 Mexico, D.F., Mexico. ${ }^{3}$ Facultad de Nutrición, Universidad Veracruzana, Médicos y Odontólogos s/n, 91010 Xalapa, Veracruz, Mexico.

SN Applied Sciences (2019) 1:361 | https://doi.org/10.1007/s42452-019-0378-7 
this study was to synthesize a steroid-oxazole-1,2'-[1,3] oxazete] derivative to evaluate their biological activity against ischemia-reperfusion injury and compare with quinalizarin (an CK2 inhibitor inhibitor). Additionally, the theoretical activity of the steroid derivative against CK2 was evaluated using a docking model.

\section{Experimental}

\subsection{General methods}

All the reagents used in this study were purchased from Sigma-Aldrich Sigma-Aldrich Co., Ltd. The melting point for compounds was evaluated on an Electrothermal $(900$ model). Infrared spectra (IR) were determined using $\mathrm{KBr}$ pellets on a Perkin Elmer Lambda 40 spectrometer. ${ }^{1} \mathrm{H}$ and ${ }^{13} \mathrm{C}$ NMR (nuclear magnetic resonance) spectra were recorded on a Varian VXR300/5 FT NMR spectrometer at $300 \mathrm{MHz}$ (megahertz) in $\mathrm{CDCl}_{3}$ (deuterated chloroform) using TMS (tetramethylsilane) as an internal standard. EIMS (electron impact mass spectroscopy) spectra were determined using a Finnigan Trace Gas Chromatography Polaris Q-Spectrometer. Elementary analysis data were determined from a Perkin Elmer Ser. II CHNS/02400 elemental analyzer.

\subsection{Chemical synthesis}

Preparation of (Z)- $\mathrm{N}-\left[(11 \mathrm{aS})-4^{\prime}, 11\right.$ a-dimethyl-3,3 a, 3b,4,5,9b, 10,11-octahydro-2H-spiro-[cyclopent a[a]phe-nan-threne-1,2'-[1,3] oxazet]-7-yl]ethanimidic acid (2) In a round bottom flask (10 ml), estradiol (200 mg, $0.73 \mathrm{mmol}$ ) and $10 \mathrm{ml}$ of acetonitrile were stirred to reflux for $12 \mathrm{~h}$. The solution obtained was reduced pressure and purified through a crystallization using the methanol:bencene (4:1) system; yielding $44 \%$ of product; m.p. $110-112{ }^{\circ} \mathrm{C}$; IR $\left(\mathrm{V}_{\text {max }} \mathrm{Cm}^{-1}\right) 3400,3322$ and $1212:{ }^{1} \mathrm{H}$ NMR (300 MHz, Chloroform-d) $\delta_{\mathrm{H}}: 0.78(\mathrm{~s}, 3 \mathrm{H}), 1.24-2.32$ $(\mathrm{m}, 12 \mathrm{H}), 3.32(\mathrm{~s}, 3 \mathrm{H}), 3.74(\mathrm{~s}, 3 \mathrm{H}), 4.36-7.16(\mathrm{~m}, 7 \mathrm{H}), 9.14$ (broad, $2 \mathrm{H})$ ppm. ${ }^{13} \mathrm{C} \mathrm{NMR}\left(300 \mathrm{~Hz}, \mathrm{CDCl}_{3}\right) \delta_{\mathrm{C}}: 11.12,17.35$, 20.02 , 20.99, 27.09, 27.6, 28.85, 28.94, 32.3, 37.67, 43.17, $45.49,48.42,95.64,117.98,120.79,131.32,133.46,136.41$, $140.22,146.28,179.09$ ppm. El-MS m/z: 352.21. Anal. Calcd. for $\mathrm{C}_{22} \mathrm{H}_{28} \mathrm{~N}_{2} \mathrm{O}_{2}: \mathrm{C}, 74.97 ; \mathrm{H}, 8.01 ; \mathrm{N}, 7.95 ; \mathrm{O}, 9.08$. Found: $\mathrm{C}$, 74.90; $\mathrm{H}, 8.00$.

Synthesis of (Z)-N-[(11 aS)-4', 11 a-dimethyl-8-nitro-3, 3a,3b,4,5,9b, 10,11-octahydro-2H-spiro[cyclopenta[a] phenanthrene-1,2'-[1,3]oxazet]-7-yl]ethanimidic acid (3) In a round bottom flask $(10 \mathrm{ml})$, compound $2(200 \mathrm{mg}$, $0.57 \mathrm{mmol})$, nitric acid $(1 \mathrm{ml})$ and anhydride acetic $(3 \mathrm{ml})$, were stirred to reflux for $4 \mathrm{~h}$. The solvent of the mixture obtained was removed under reduced pressure and purified through a crystallization using the methanol:water (4:1) system; yielding $37 \%$ of product; m.p. $86-88^{\circ} \mathrm{C}$; IR $\left(\mathrm{V}_{\text {max }} \mathrm{Cm}^{-1}\right)$ 3400, 3320, 1486 and 1212: ${ }^{1} \mathrm{H}$ NMR $(300 \mathrm{MHz}$, Chloroform-d) $\delta_{\mathrm{H}}: 0.75(\mathrm{~s}, 3 \mathrm{H}), 1.65-2.10(\mathrm{~m}, 12 \mathrm{H}), 2.49(\mathrm{~s}$, $3 \mathrm{H}), 4.15(\mathrm{~s}, 3 \mathrm{H}), 5.47-8.32(\mathrm{~m}, 7 \mathrm{H}), 8.63$ (broad, 1H) ppm. ${ }^{13} \mathrm{C}$ NMR $\left(300 \mathrm{~Hz}, \mathrm{CDCl}_{3}\right) \delta_{\mathrm{C}}: 11.12,17.35,20.02,20.99$, $27.09,27.62,28.85,28.94,32.32,37.67,43.58,45.49,48.42$, $95.64,125.07,126.44,133.46,136.78,137.95,142.12$, 148.55, 181.27 ppm. El-MS m/z: 397.20. Anal. Calcd. for $\mathrm{C}_{22} \mathrm{H}_{27} \mathrm{~N}_{3} \mathrm{O}_{4}: \mathrm{C}, 66.48 ; \mathrm{H}, 6.85 ; \mathrm{N}, 10.57 ; \mathrm{O}, 16.10$. Found: $\mathrm{C}$, $66.40 ; \mathrm{H}, 6.80$.

Preparation of (18'S)-4,6',18'-trimethyl-5'-oxa-7'-aza spiro[1,3-oxazete-2,17'-penta-cyclo[11.7.0.0 ${ }^{2},{ }^{10} .0^{4},{ }^{8}$. $0^{14},{ }^{18}$ ]icosane]-2' $\left(10^{\prime}\right), 3^{\prime}, 6^{\prime}, 8^{\prime}$-tetraene (4) In a round bottom flask $(10 \mathrm{ml})$, compound $3(100 \mathrm{mg}, 0.50 \mathrm{mmol})$, potassium carbonate anhydrous $(50 \mathrm{mg}, 0.36 \mathrm{mmol}$ ) in $5 \mathrm{ml}$ of dimethyl sulfoxide were stirred to room temperature for $48 \mathrm{~h}$. The solvent of the mixture obtained was removed under reduced pressure and purified through a crystallization using the methanol:bencene (4:1) system; yielding $37 \%$ of product; m.p. $58-60{ }^{\circ} \mathrm{C} ; \mathrm{IR}\left(\mathrm{V}_{\text {max }} \mathrm{cm}^{-1}\right)$ 3320 and 1114: ${ }^{1} \mathrm{H}$ NMR $\left(300 \mathrm{MHz}\right.$, Chloroform-d) $\delta_{\mathrm{H}}: 0.96$ $(\mathrm{s}, 3 \mathrm{H}), 1.29-2.61(\mathrm{~m}, 9 \mathrm{H}), 2.67(\mathrm{~s}, 3 \mathrm{H}), 3.43(\mathrm{~m}, 1 \mathrm{H}), 3.49(\mathrm{~s}$, $3 \mathrm{H}), 3.54-8.36(\mathrm{~m}, 4 \mathrm{H}) \mathrm{ppm} .{ }^{13} \mathrm{C} \mathrm{NMR}\left(300 \mathrm{~Hz}, \mathrm{CDCl}_{3}\right) \delta_{\mathrm{c}}$ : $11.10,14.32,17.32,20.00,27.06,27.62,28.85,28.94,32.32$, $37.67,44.02,45.49,48.42,95.64,107.32,118.44,133.00$, 133.42, 135.90, 140.04, 146.40, 163.82 ppm. El-MS m/z: 350.19. Anal. Calcd. for $\mathrm{C}_{22} \mathrm{H}_{26} \mathrm{~N}_{2} \mathrm{O}_{2}$ : C, 75.40; $\mathrm{H}, 7.48 ; \mathrm{N}$, 7.99; $\mathrm{O}, 9.13$. Found: $\mathrm{C}, 75.36 ; \mathrm{H}, 7.42$.

\subsection{Theoretical evaluation of the pharmacological activity of steroid analogues}

Some physicochemical parameters of compounds 2-4 were determined to determine the oral availability of the drug and its pharmacokinetic properties using SwissADME, Spartan and ACD/Chem Sketch softwars [23-25].

\subsection{Pharmacophore evaluation}

The 3D pharmacophore model for the compounds 2, 3 and 4 was determinate using LigandScout 4.08 software [26].

\section{Biological methods}

All experimental procedures and protocols used in this investigation were reviewed and approved by the Animal care and use Committee of University Autonomous of Campeche (no. Pl-420/12) and were in accordance with the Guide for the Care and Use of Laboratory Animals [27]. 
Male Wistar rats, weighing 200-250 g, were obtained from University Autonomous of Campeche.

\subsection{Reagents}

All drugs were dissolved in methanol and different dilutions were obtained using Krebs-Henseleit solution $(\leq 0.01 \%, \mathrm{v} / \mathrm{v})$.

\subsection{Experimental design}

Briefly, the male rat $(200-250 \mathrm{~g})$ was anesthetized by injecting them with pentobarbital at a dose rate of $50 \mathrm{mg} /$ $\mathrm{Kg}$ body weight. Then the chest was opened, and a loose ligature passed through the ascending aorta. The heart was then rapidly removed and immersed in ice cold physiologic saline solution. The heart was trimmed of noncardiac tissue and retrograde perfused via a noncirculating perfusion system at a constant flow rate. The perfusion medium was the Krebs-Henseleit solution $\left(\mathrm{pH}=7.4,37^{\circ} \mathrm{C}\right)$ composed of (mmol) $117.8, \mathrm{NaCl} ; 6, \mathrm{KCl} ; 1.75, \mathrm{CaCl}_{2} ; 1.2$, $\mathrm{NaHPO}_{4} ; 1.2, \mathrm{MgSO}_{4} ; 24.2, \mathrm{NaHCO}_{3} ; 5$, glucose; 7 and 5, sodium pyruvate. The solution was actively bubbled with a mixture of $\mathrm{O}_{2} / \mathrm{CO}_{2}(95: 5 / 5 \%)$. The coronary flow was adjusted with a variable speed peristaltic pump [27]. An initial perfusion rate of $15 \mathrm{~mL} / \mathrm{min}$ for $5 \mathrm{~min}$ was followed by a $15 \mathrm{~min}$ equilibration period at a perfusion rate of $10 \mathrm{~mL} / \mathrm{min}$. All experimental measurements were done after this equilibration period.

\subsection{Perfusion pressure}

Evaluation of measurements of perfusion pressure changes induced by drugs administration in this study was assessed using a pressure transducer connected to the chamber where the hearts were mounted, and the results entered into a computerized data capture system (Biopac).

\subsection{First stage}

Effect induced by the compounds 2-4 on perfusion pressure. Evaluation of changes in perfusion pressure through of the increases in time (3-18 $\mathrm{min}$ ) in absence (control) or presence of compounds 2,3 and 4 [0.001 nM] were determined. The effects were obtained in isolated hearts perfused at a constant-flow rate of $10 \mathrm{ml} / \mathrm{min}$.

\subsection{Second stage}

Biological activity induced by the quinalizarin and compounds 2, 3 and 4 on infarct area using an ischemia/reperfusion model. After of 15 -min equilibration time, the hearts were subjected to ischemia for $30 \mathrm{~min}$ by turning off the perfusion system [28]. After this period, the system was restarted, and the hearts were reperfused by 30 min with Krebs-Henseleit solution. The hearts were randomly divided into 5 major treatment groups with $\mathrm{n}=9$ as following:

Group I. Hearts were subjected to ischemia/reperfusion but received vehicle only (Krebs-Henseleit solution).

Group II. Hearts were subjected to ischemia/reperfusion and treated with quinalizarin.

Group III. Hearts were subjected to ischemia/reperfusion and treated with the compound $2(0.001 \mathrm{nM}]$. Group IV. Hearts were subjected to ischemia/reperfusion and treated with the compound $3(0.001 \mathrm{nM}]$. Group V. Hearts were subjected to ischemia/reperfusion and treated with the compound 4 (0.001 nM].

It is important to mention that dose administered were carried out before ischemia period (for $10 \mathrm{~min}$ ) and during the entire period of reperfusion. At the end of each experiment, the perfusion pump was stopped, and $0.5 \mathrm{ml}$ of fluorescein solution $(0.10 \%)$ was injected slowly through a sidearm port connected to the aortic cannula. The dye was passed through the heart for $10 \mathrm{~s}$ to ensure its uniform tissue distribution. The presence of fluorescein was used to demarcate the tissue that was not subjected to regional ischemia, as opposed to the risk region. The heart was removed from the perfusion apparatus and cut into two transverse sections at right angles to the vertical axis. The right ventricle, apex, and atrial tissue were discarded. The areas of the normal left ventricle non-risk region, area at risk, and infarct region were determined using methods previously reported [29]. Total area at risk was expressed as the percentage of the left ventricle.

\subsection{Efect exerted by the compound 4 on infarct area using an ischemia/reperfusion model}

The hearts were subjected to ischemia for $30 \mathrm{~min}$ in absence or presence of the compound 4 at dose of $0.001-100 \mathrm{nM}$.

\subsection{Theoretical evaluation of the interaction between compound 4 and kinase- 2 protein (3FL5)}

The interaction of compound 4 with 3FL5 [30] was carried out using a DockingServer [31]. Additionally, quinalizarin was used as control. 


\subsection{Statistical analysis}

The obtained values are expressed as average \pm SE. The data obtained were put under analysis of variance (ANOVA) with the Bonferroni correction factor using the SPSS 12.0 program [32]. The differences were considered significant when was equal or smaller than 0.05 .

\section{Results and discussion}

Some data indicate that several drugs can exert biological activity against casein kinase $2[18,19]$; therefore, in this study, a steroid-[2,3- $d]$ oxazole-1,2'-[1,3] oxazete derivative was prepared for their biological evaluation using an ischemia/reperfusion model. The first stage was achieved by the synthesis of some steroid derivatives as follows:

\subsection{Preparation of a spiro-steroid-ethanimidic acid derivative}

There are several reports to synthesis of spiro derivatives which use some reagents such as thiophene [33], N-chlorosuccinamide [34], sulfur ylide derivative [35], iodobenzene diacetate [36], $\mathrm{FeCl}_{3}$ [37]. In this study, a spiro-steroidethanimidic acid derivative (compound 2) was prepared from estradiol (1) and nitrile (Fig. 1).

The ${ }^{1} \mathrm{H}$ NMR spectra for 2 (Fig. 3) showed several signals at $0.79 \mathrm{ppm}$ for methyl bound to steroid nucleus; at $1.24-2.32$ and $4.36-7.16$ ppm for steroid moiety: at
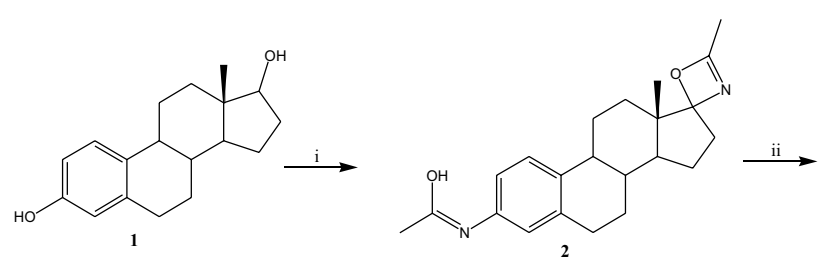

Fig. 1 Synthesis of steroid-oxazole-1,2'-[1,3] oxazete] derivative (4). Reaction of estradiol (1) with acetonitrile (i) to form a spiro-steroid ethanimidic acid analog (2). Then, a nitro-spiro-steroid ethanimidic acid (3) was prepared trough of reaction of 2 with nitric acid (ii). Finally, 4 was formed via intramolecular displazament of nitro by hydroxyl group. It is important to mention that this reaction involves two reaction mechanism; (i) preparation of an acetamidic acid via reaction of nitrile to hydroxyl group bound to ring-A; (ii) formation of spiro system by reaction of acetonitrile to 17-hydroxyl group of steroid derivative (Fig. 2)

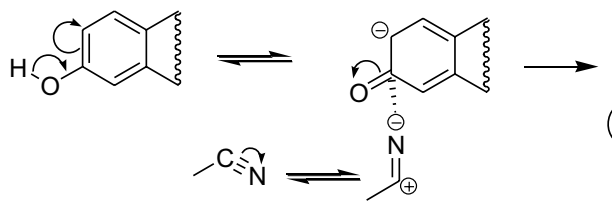

2

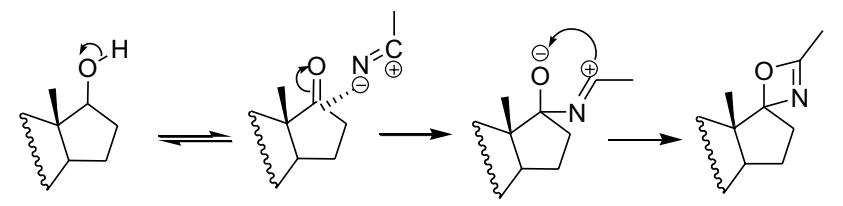

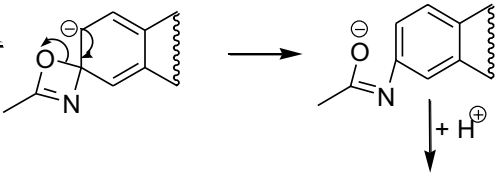<smiles>CC(O)=Nc1ccc2c(c1)CC2</smiles>

Fig. 2 Mechanism of reaction involved in the synthesis of a spiro-steroid ethanimidic acid derivative 


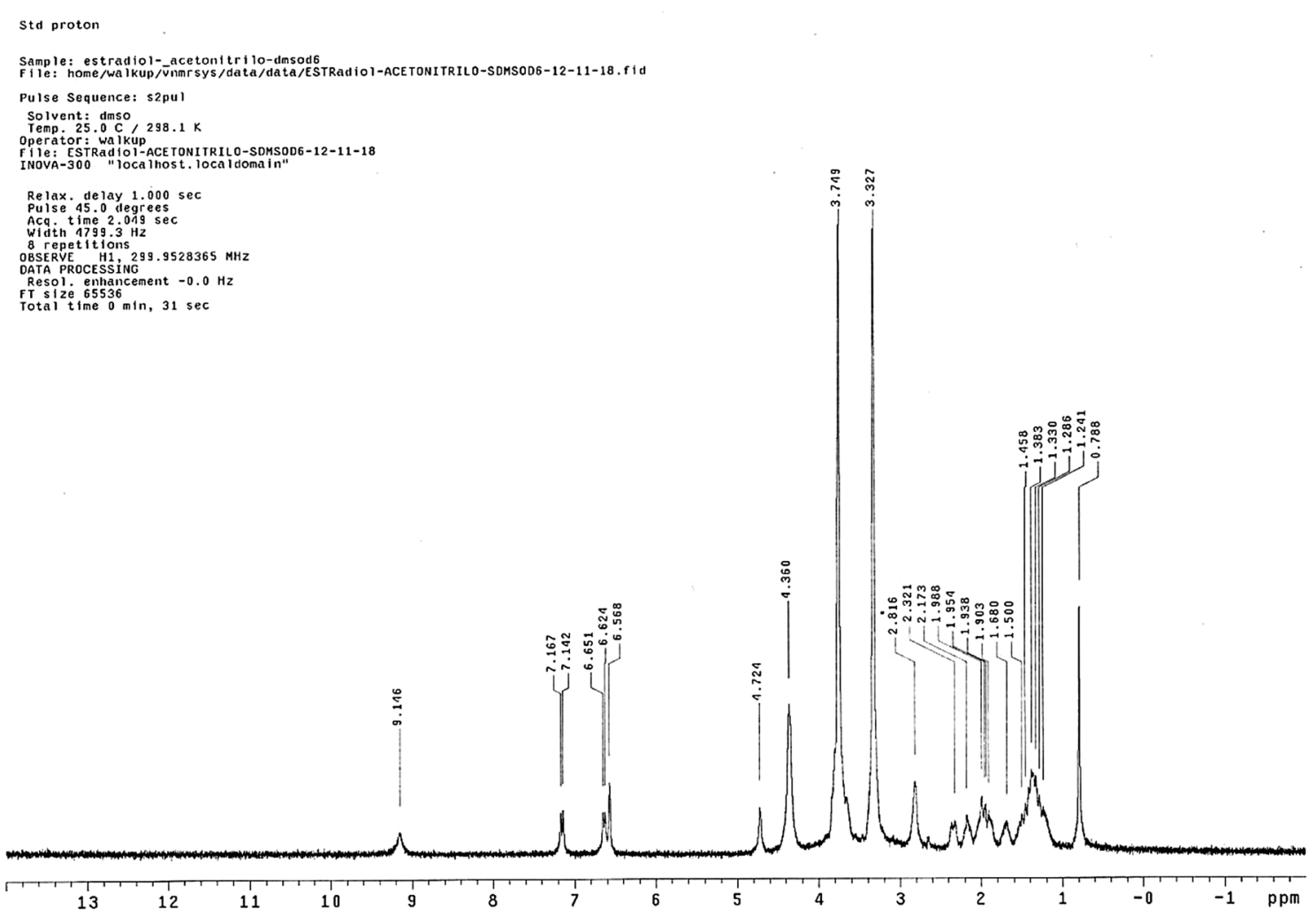

Fig. 3 The scheme shown ${ }^{1} \mathrm{H}$ NMR spectrum of compound 2. Analyzed with a Varian VXR300/5 FT NMR apparatus at 300 and 75.4 MHz in $\mathrm{CDCl}_{3}$

$3.32 \mathrm{ppm}$ for methyl bound to both hydroxyl and imino groups; at $3.74 \mathrm{ppm}$ for methyl bound to $2 \mathrm{H}-[1,3]$ Oxazete ring; at $9.14 \mathrm{ppm}$ for hydroxyl group. ${ }^{13} \mathrm{C}$ NMR spectra for 2 showed several signals at $11.10 \mathrm{ppm}$ for methyl bound to steroid nucleus; at $17.32 \mathrm{ppm}$ for $2 \mathrm{H}-[1,3]$ Oxazete ring; at $21.00 \mathrm{ppm}$ for methyl bound to both hydroxyl and imino groups; at 20.00, 25.10-131.30 and 136.40-146.31 ppm for steroid moiety; at $133.42 \mathrm{ppm}$ for $2 \mathrm{H}-[1,3]$ Oxazete ring; at $179.02 \mathrm{ppm}$ for imino group. In addition, the compound 2 showed a molecular ion $(\mathrm{m} / \mathrm{z})$ at 352.47 .

\subsection{Preparation of a spiro-steroid-oxazet- ethanimidic acid derivative}

Some reagents have used to synthesis of nitro-derivatives such as Montmorrolinate $\mathrm{KSF}-\mathrm{Bi}\left(\mathrm{NO}_{3}\right)_{3}[38], \mathrm{Bi}\left(\mathrm{NO}_{3}\right)_{3} / 5 \mathrm{H}_{2} \mathrm{O}$ [39], $\mathrm{Cu}\left(\mathrm{NO}_{3}\right)_{2}$ [40] and others. In this study, the nitration of compound 2 was carried out via $\mathrm{HNO}_{3}$ /Acetic acid (Fig. 1). The ${ }^{1} \mathrm{H}$ NMR spectra for 3 (Fig. 4) showed several signals at $0.75 \mathrm{ppm}$ for methyl bound to steroid nucleus; at $1.65-2.10,5.48-8.32 \mathrm{ppm}$ for steroid moiety; at $2.49 \mathrm{ppm}$ for methyl bound to both hydroxyl and imino groups; at $4.15 \mathrm{ppm}$ for methyl bound to $2 \mathrm{H}-[1,3]$ Oxazete ring; at $8.63 \mathrm{ppm}$ for hydroxyl group. ${ }^{13} \mathrm{C}$ NMR spectra for 3 showed several signals at $11.10 \mathrm{ppm}$ for methyl bound to steroid nucleus; at $17.32 \mathrm{ppm}$ for methyl group bound to $2 \mathrm{H}-[1,3]$ Oxazete ring; at $21.10 \mathrm{ppm}$ for methyl bound to both hydroxyl and imino groups; at 20.00, 27.10-126.44 and $136.75-148.52 \mathrm{ppm}$ for steroid moiety; at $133.44 \mathrm{ppm}$ for $2 \mathrm{H}-[1,3]$ Oxazete ring; at $181.24 \mathrm{ppm}$ for imino group. Additionally, 3 showed a molecular ion (m/z) at 397.20.

\subsection{Preparation of a steroid-oxazole-1,2'-[1,3] oxazete] derivative}

Several oxazete derivatives have been synthetized using some reagents such as mesitonitrile oxide [41], a,a-bis(alkylthio) oxime [42], acylisothiocyanate [43] and others. In this study, an azete derivative was prepared via intramolecular reaction by displazament of nitro group in mild conditions (Fig. 1). The ${ }^{1} \mathrm{H}$ NMR spectra for 4 (Fig. 5) showed several signals at $0.96 \mathrm{ppm}$ for methyl bound to steroid nucleus; at 1.29-2.61, 3.43 and 3.54-8.36 ppm for steroid moiety; at $2.67 \mathrm{ppm}$ for methyl group bound to $2 \mathrm{H}-[1,3]$ Oxazete ring; at $3.44 \mathrm{ppm}$ for methyl bound to both hydroxyl and imino groups. ${ }^{13} \mathrm{C}$ NMR spectra for 4 showed several signals at $11.10 \mathrm{ppm}$ for methyl bound to steroid nucleus; at $14.32 \mathrm{ppm}$ for methyl bound to both hydroxyl and imino groups; at $17.32 \mathrm{ppm}$ for methyl bound to $2 \mathrm{H}-[1,3]$ Oxazete ring; at 20.00-133.00 and 


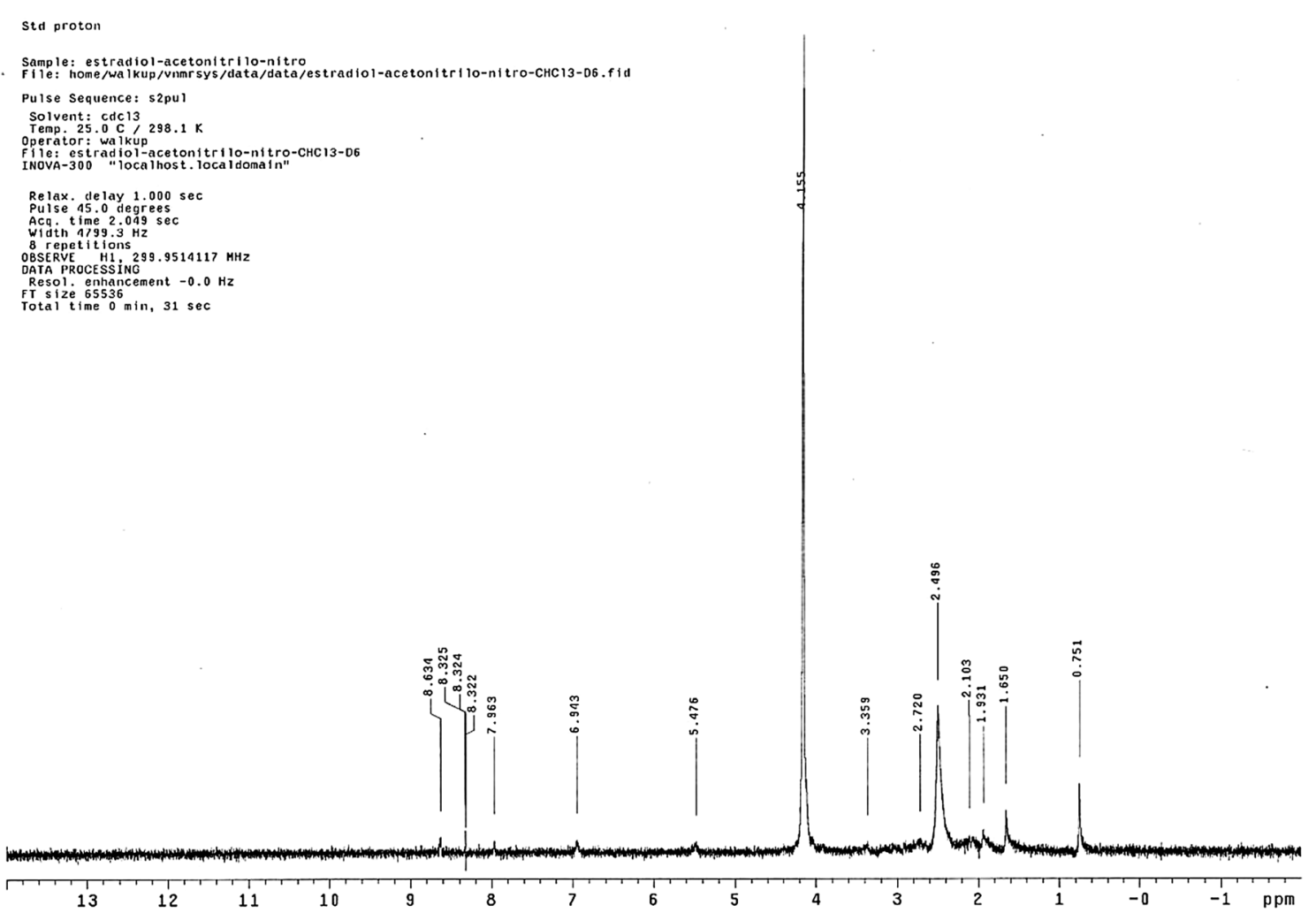

Fig. 4 The scheme shown ${ }^{1} \mathrm{H}$ NMR spectrum of compound 3. Analyzed with a Varian VXR300/5 FT NMR apparatus at 300 and $75.4 \mathrm{MHz}$ in $\mathrm{CDCl}_{3}$

135.90-146.40 ppm for steroid moiety; at $133.42 \mathrm{ppm}$ for imino group bound to hydroxyl group; at $163.82 \mathrm{ppm}$ for $2 \mathrm{H}-[1,3]$ Oxazete ring. Finally, 4 showed a molecular ion $(\mathrm{m} / \mathrm{z})$ at 350.19 .

\subsection{Physicochemical parameters}

In order to delineate the structural chemical requirements of compound 2, 3 and 4, some physicochemical parameters such as the molar volume $\left(\mathrm{V}_{\mathrm{m}}\right)$ and molar refractivity $\left(R_{m}\right)$ that are steric constant which could induce changes in some biological activities were evaluated using ACD/ Chem Sketch algorithms [24].

The results showed that both $R_{m}$ and $V_{m}$ values were lower for 4 compared with the values for the compounds 2 and 3 (Table 1). These results indicate that steric impediment, conformational preferences and internal rotation of 2 and 3 could influence some biological activity exerted these compounds in comparison with 4.

\subsection{Pharmacophore modelling}

There are some studies that indicate that the pharmacophore is the three-dimensional orientation adopted by the functional groups of a molecule to be able to interact with some proteins [44]. This pharmacophore model can furnish a new insight to design novel molecules that can enhance or inhibit the function of the target and will be useful in drug discovery strategies. Therefore, in this study, LigandScout software [26] was used to develop a pharmacophore model of compounds $2-4$. The results showed in the Fig. 6 indicated that there is different type of functional groups involved in the compounds 2, 3 and 4 that can interact via hydrophobic contacts or as hydrogen bond acceptors or as hydrogen bond donor with some biomolecules (Table 1).

\subsection{Pharmacokinetic theoretical evaluation}

Some pharmacokinetic parameters of compounds 2-4 were evaluated using SWISSADME predictor. The results (Table 2 ) showed that compounds 2-4 could be absorbed via oral and the compounds 2 and 4 show higher lipophilicity compared with compound 3 (Table 3). In addition, other data indicate differences in the interaction with CYP proteins which results changes of metabolism such happening with other drugs [45].

\section{SN Applied Sciences}




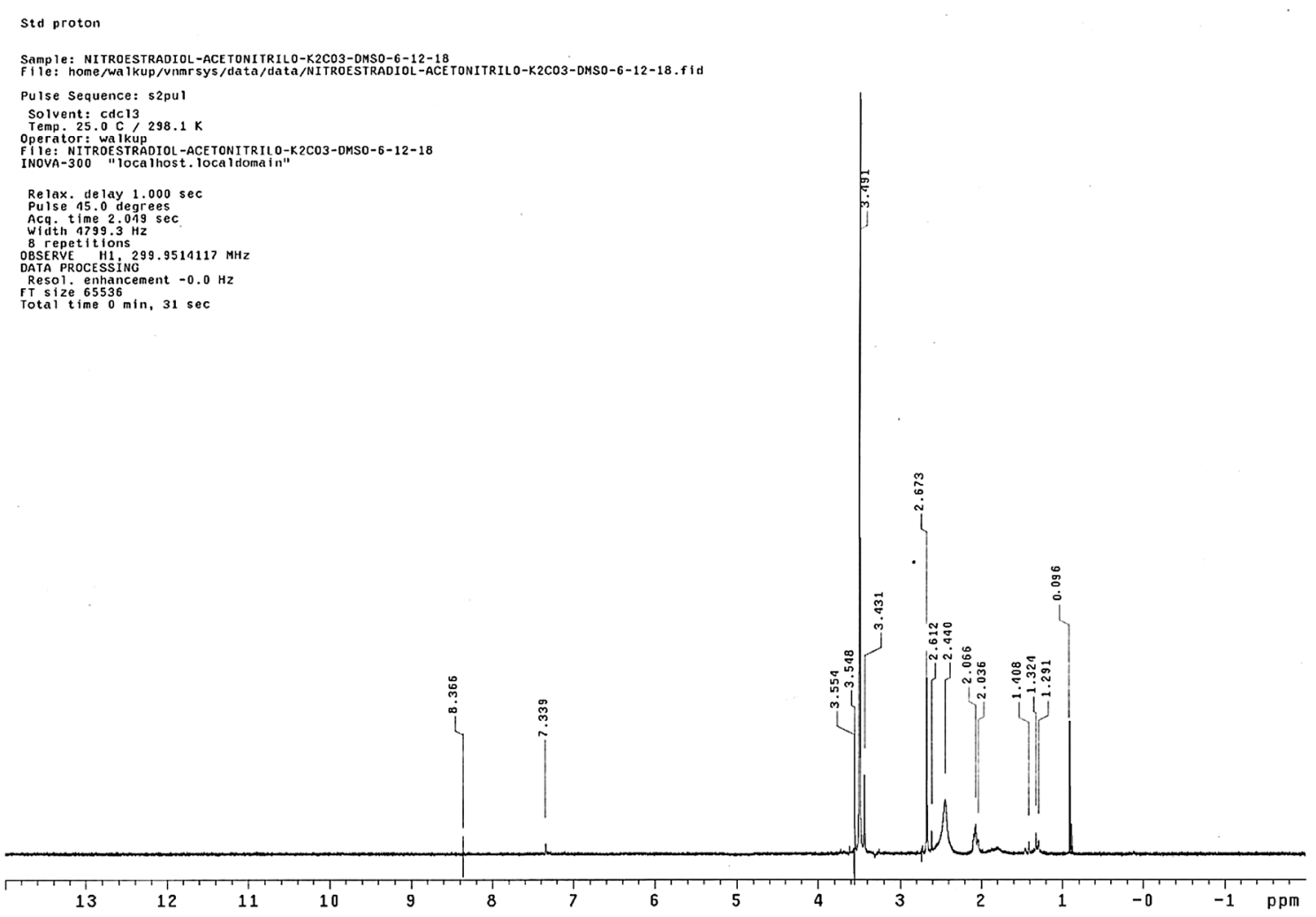

Fig. 5 The scheme shown ${ }^{1} \mathrm{H}$ NMR spectrum of compound 4. Analyzed with a Varian VXR300/5 FT NMR apparatus at 300 and 75.4 MHz in $\mathrm{CDCl}_{3}$

Table 1 Physicochemical parameters of compounds 2, 3 and 4. The values were calculated using both ACDLabs and Spartan softwars

\begin{tabular}{llll}
\hline Parameters & 2 & 3 & 4 \\
Molar volume $\left(\mathrm{cm}^{3}\right)$ & 265.30 & 270.60 & 246.00 \\
Molar refractivity $\left(\mathrm{cm}^{3}\right)$ & 100.04 & 105.70 & 96.03 \\
Polarizability $\left(\mathrm{cm}^{3}\right)$ & 39.28 & 41.18 & 39.72 \\
Parachor $\left(\mathrm{cm}^{3}\right)$ & 701.30 & 746.80 & 660.00 \\
Index of refraction & 1.67 & 1.70 & 1.72 \\
Surface tension $($ dyne/cm) & 48.70 & 57.90 & 51.70 \\
Density $\mathrm{g} / \mathrm{cm}^{3}$ & 1.32 & 1.46 & 1.42 \\
HBD & 1 & 1 & 0 \\
$\mathrm{HBA}$ & 3 & 5 & 2 \\
$\mathrm{Pka}$ & 14.65 & 11.26 & 1.5 \\
\hline
\end{tabular}

\subsection{Biological activity evaluation "in vitro"}

There are some reports which indicate that some steroid derivatives can exert changes in the perfusion pressure in vitro [46]. To evaluate this data, the biological activity induced by the compounds 2-4 on perfusion pressure (translated as changes in on blood vessel capacity and coronary resistance) was evaluated using an isolated rat heart model. The results showed that compound 4 significantly increase $(p=0.05)$ the perfusion pressure over time (3-18 $\mathrm{min}$ ) compared with the compounds 2 , 3 and control conditions (Fig. 7). These data suggest that the activity exerted by compound $\mathbf{4}$ on the perfusion pressure is due to different functional groups involved in its chemical structure.

Analysing these results, other studies were carried out to evaluate the biological activity of compounds 2-4 [0.001 nM] on myocardial injury using an ischemia/ reperfusion model.

The results showed that compound 4 significantly reduced $(p=0.05)$ infarct size (expressed as a percentage of the area at risk) compared with the controls conditions and the compounds 2 and 3 (Fig. 8). Analysing these data, other alternative experiments were carried out, with the purpose of evaluating whether increases in the dose exert a greater effect of the compound 7 against infarct size. The results indicate that this phenomenon was in dose-dependent manner compared with the control conditions (Fig. 9).

In the search, of molecular mechanism involved in the biological activity of compound 4 against ischemia/ reperfusion injury some studies were analysed, these reports indicate that some biomolecules such as casein kinase 2 (CK2) could be involved in the regulation of 


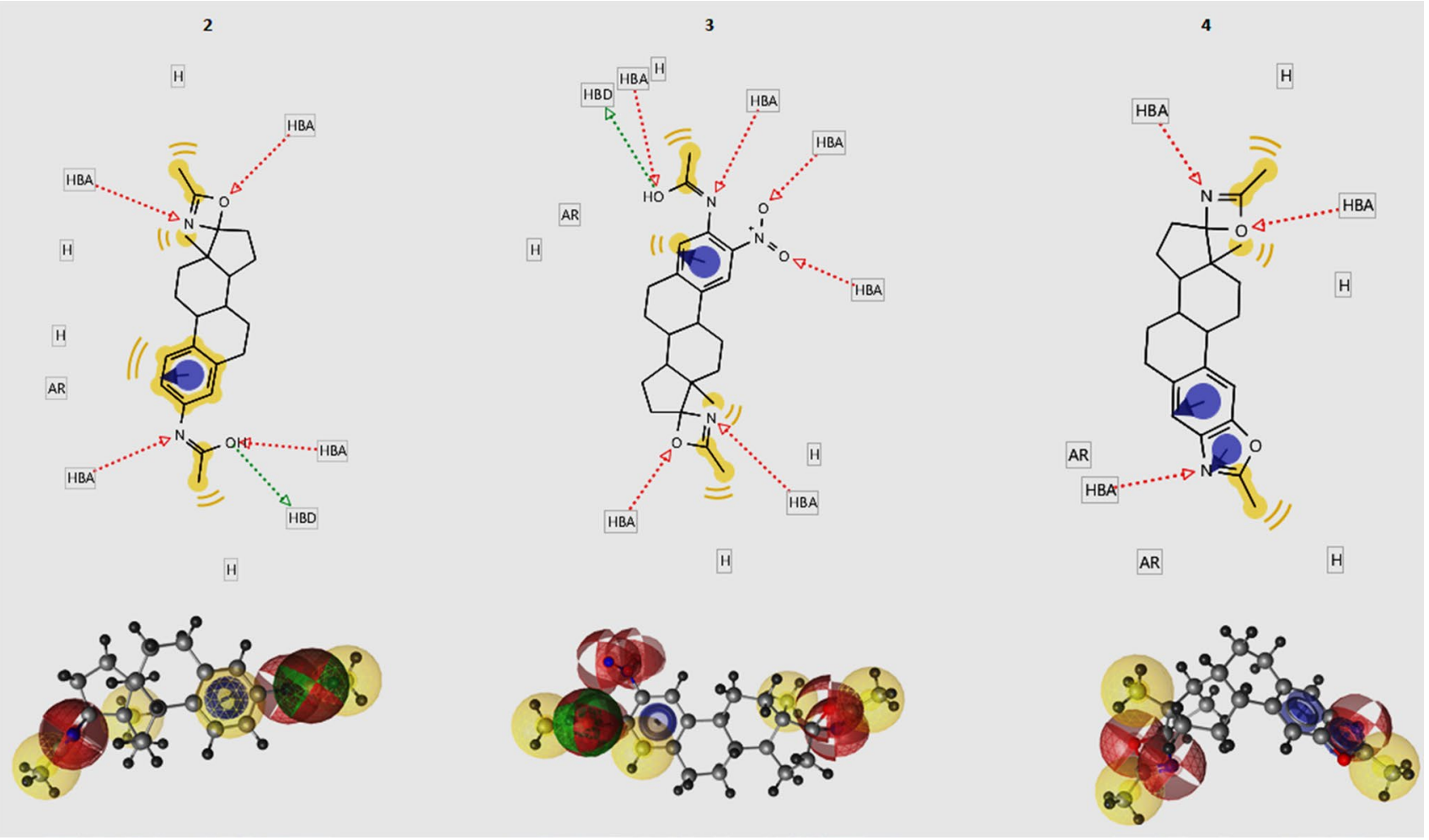

Fig. 6 Scheme represents a pharmacophore from both compounds 2, 3 and 4 using the LigandScout software. The model involves a methyl group (yellow) hydrogen bond acceptors (HBA, red), hydrogen bond donor (HBD, green) and a positive ionizable (PI)

Table 2 The pharmacokinetics properties of compounds $2-4$. The values determinate using the SwissADME software

\begin{tabular}{lllllllllll}
\hline Comp & Gl (absorption) & $\begin{array}{l}\text { BBB (per- } \\
\text { meant) }\end{array}$ & $\begin{array}{l}\text { P-gP } \\
\text { (sub- } \\
\text { strate) }\end{array}$ & $\begin{array}{l}\text { CYP1A2 } \\
\text { inhibitor }\end{array}$ & $\begin{array}{l}\text { CYP2C19 } \\
\text { inhibitor }\end{array}$ & $\begin{array}{l}\text { CYP2C9 } \\
\text { inhibitor }\end{array}$ & $\begin{array}{l}\text { CYP2D6 } \\
\text { inhibitor }\end{array}$ & $\begin{array}{l}\text { CYP3A4 } \\
\text { inhibitor }\end{array}$ & Lipinski viol. & Drug-likeness \\
\hline 2 & High & Yes & Yes & Yes & Yes & Yes & No & Yes & 0 & Yes \\
3 & High & No & Yes & No & Yes & Yes & No & No & 0 & Yes \\
4 & High & Yes & No & No & Yes & Yes & Yes & No & 1 & Yes \\
\hline
\end{tabular}

Table 3 Lipophilicity degree of compounds $2-4$

\begin{tabular}{lllllll}
\hline Compound & iLogP & XLogP3 & WLogP & MLogP & Silicos-1T & $\begin{array}{l}\text { Con- } \\
\text { sensus } \\
\text { LogP }\end{array}$ \\
\hline 2 & 3.80 & 3.97 & 4.91 & 4.15 & 5.02 & 4.37 \\
3 & 3.34 & 3.94 & 4.82 & 3.18 & 2.85 & 3.63 \\
4 & 3.88 & 4.65 & 4.76 & 3.93 & 5.95 & 4.49 \\
\hline
\end{tabular}

The values determinate using the SwissADME software some biochemical phenomena produced in the infarct by ischemia injury $[13,15]$.

To evaluate this hypothesis in this study the biological activity of quinalizarin (CK2 inhibitor) ischemia/ reperfusion injury was evaluated to compare with the effect exerted by the compound 4. The results showed (Fig. 10) that quinalizarin decrease the infarction area and this effect was similar to effect produced by the 


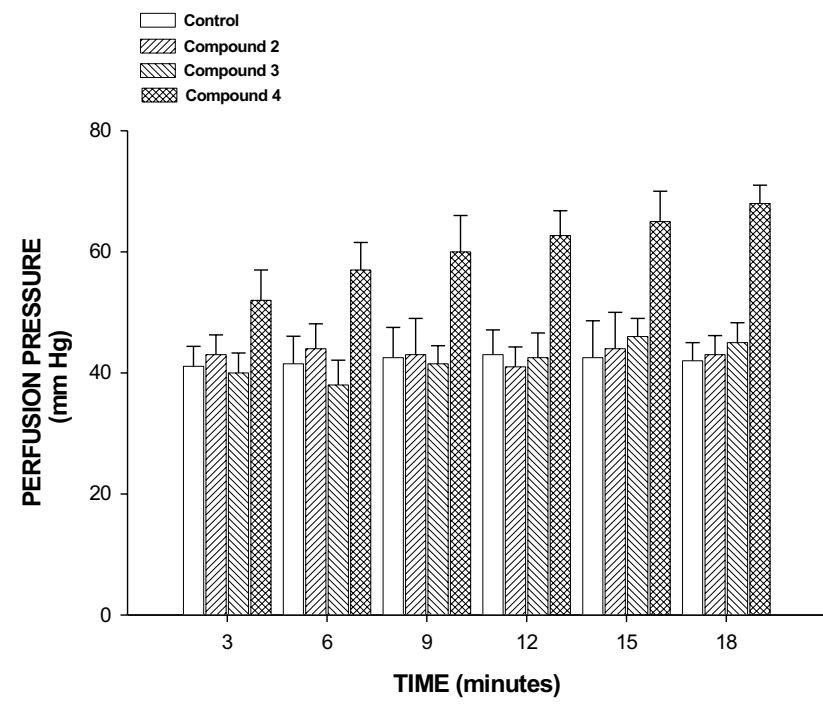

Fig. 7 Effect induced by the compounds 2-4 on perfusion pressure. The results showed in the graphic indicate that perfusion pressure was higher $(p=0.05)$ in presence of compound 4 compared with compounds 2, 3 and conditions control. Each bar represents the mean \pm S.E. of 9 experiments

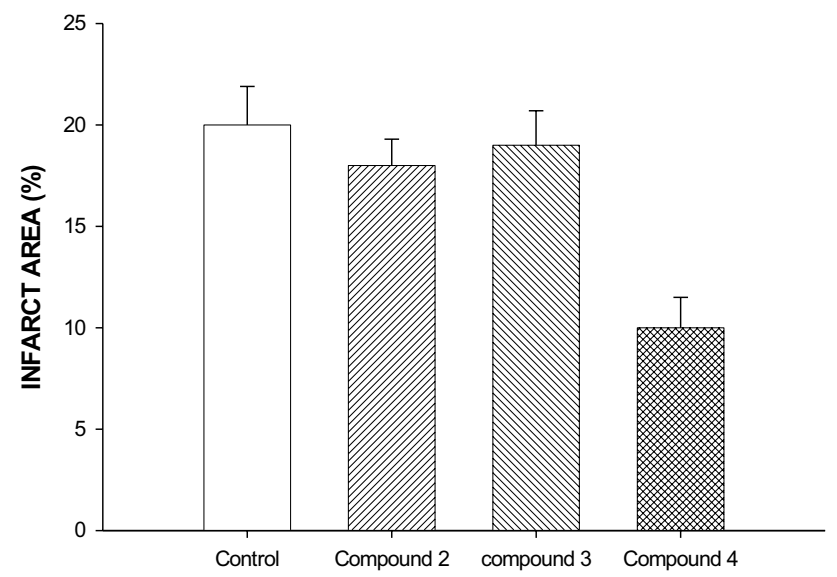

Fig. 8 Effect exerted by compounds $2-4$ at a dose of $0.01 \mathrm{nM}$ on the functional recovery of rat hearts subjected to ischemia and reperfusion. The results indicate that the compound 4 significantly $(p=0.05)$ reduce the area infarct in comparison in comparison with the compound 2 and $3[0.01 \mathrm{nM}]$ and control conditions. Each bar represents the mean \pm S.E. of 9 experiments

compound 4 on ischemia/reperfusion injury; these data indicate that compound 4 may act as CK2-inhibitor.

\subsection{Evaluation of interaction of compounds 3-7 with kinase-2 protein (3FL5)}

Since several years ago, some theoretical models have been used to predict the interaction of some drugs with protein or enzymes [47]. Therefore, in this study was

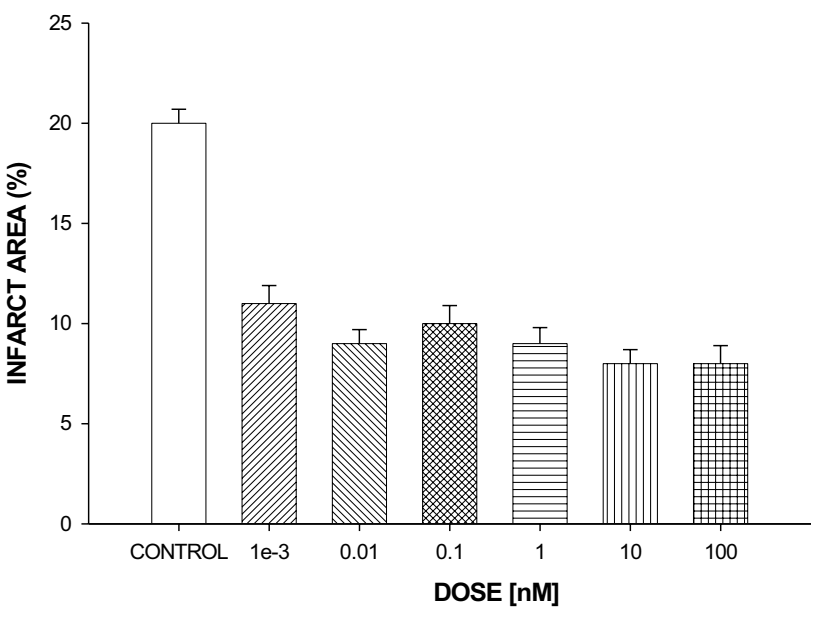

Fig. 9 Biological activity exerted by compound 4 at a dose of $0.001-100 \mathrm{nM}$ on the functional recovery of rat hearts subjected to ischemia and reperfusion. The results indicate that the compound 4 reduce the area infarct to different dose compared with control conditions. Each bar represents the mean \pm S.E. of 9 experiments

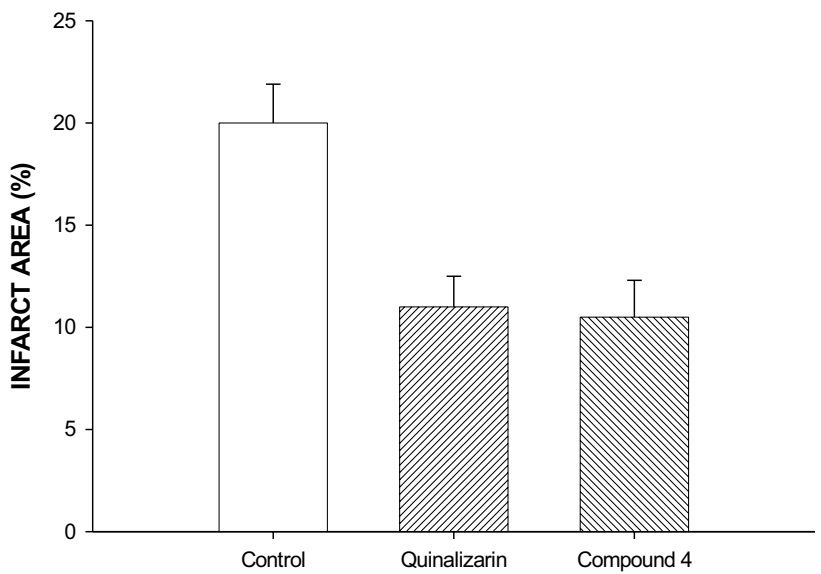

Fig. 10 Effect exerted by compounds 4 and quinalizarin at a dose of $0.01 \mathrm{nM}$ on the functional recovery of rat hearts subjected to ischemia and reperfusion. The results indicate that the compound 4 significantly $(p=0.05)$ reduce the area infarct compared with the control conditions. However, there were no significant differences in comparison with the biological activity exerted by quinalizarin. Each bar represents the mean \pm S.E. of 9 experiments

carried out a theoretical analysis on interaction of compounds 4 with CK2 protein (3FL5) [30] using a Docking model [31]. The results shown the interaction of compounds 4 with some amino acid residues involved in 3FL5 protein surface such as $\mathrm{Gln}_{86}, \mathrm{Lys}_{96}, \mathrm{Leu}_{97}, \mathrm{Leu}_{98}$. It is important to mention that the interaction of quinalizarin with $3 \mathrm{FL} 5$ protein was also evaluated to compare it with the theoretical coupling of compound $\mathbf{4}$ with this protein. The results (Fig. 11, Table 4) showed that quinalizarin 


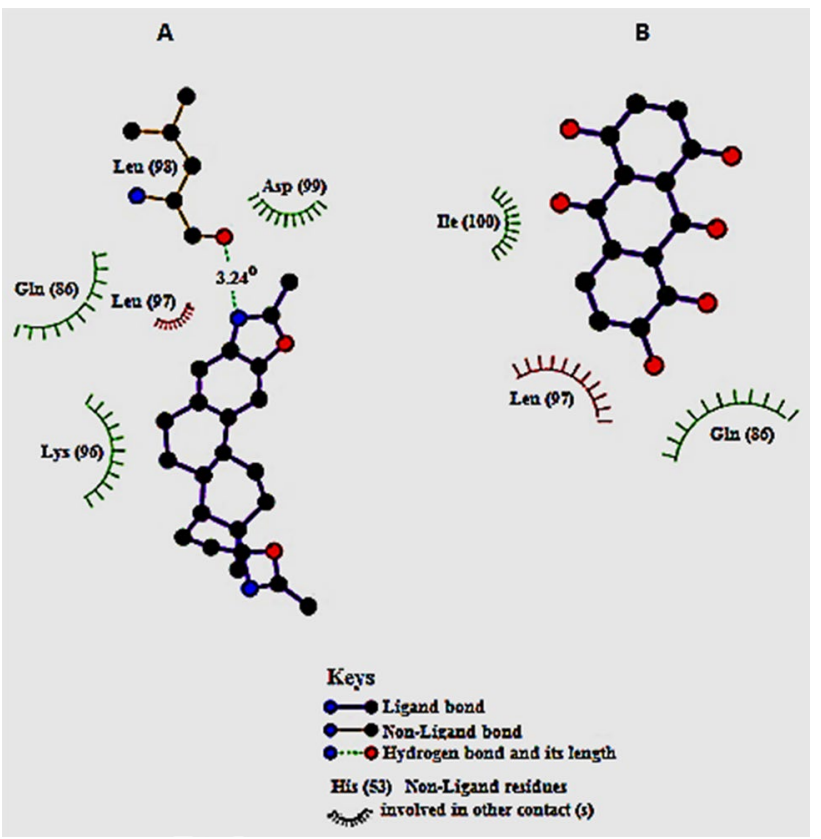

Fig. 11 The scheme shows the binding sites of compound $4(A)$ and quinalizarin $(B)$ with some aminoacid residues involved on protein kinase surface (3FL5). The visualization was carried out using DockingServer software
Table 4 Residues of aminoacids involved in the interaction between quinalizarin and compounds 4 and with 3 FL5 protein surface

\begin{tabular}{ll}
\hline Compound 4 & Quinalizarin \\
\hline Gln $_{86}$ & Gln $_{86}$ \\
Lys $_{96}$ & $\operatorname{Leu}_{97}$ \\
Leu $_{97}$ & $\mathrm{Ile}_{100}$ \\
Leu $_{98}$ & \\
\hline
\end{tabular}

The values were determinate using the DockingServer software

could interact with some aminoacid residues such as $\mathrm{Gl} \mathrm{n}_{86}$ Leu $_{97},{ }_{1} e_{100}$ of $3 F L 5$ protein.

These data suggest that both $\mathrm{Gln}_{86}$ and $\mathrm{Leu}_{97}$ may specific to the biological activity of kinase-2 protein (3FL5) and this phenomenon could be inhibited by the presence of quinalizarin or the compound 4. However, this biological effect could involve other type intramolecular interactions due to changes in the energy levels.

\subsection{Thermodynamic parameters}

There are studies which indicate that several thermodynamic parameters could be involved in the interaction drug-protein [48]. Analyzing these data, in this study a theoretical ass was carried out to evaluate some thermodynamic factors involved in the interaction of quinalizarin and the compound 4 with the 3FL5 protein such as (1) free energy of binding which determinate the energy value that require a molecule to interact with a protein in a water environment. (2) Electrostatic energy that is the product of electrical charge and electrostatic potential, which are involved in the ligand-protein system; 3 ) total intermolecular energy and (4) Van der Waals (vdW) + hydrogen bond (Hbond) + desolvation energy (Desolv. Energy; which have an influence on the movement of water molecules into or out of the ligand-protein system) using a theoretical model [26]. The results showed that there are differences in the thermodynamic parameters of compound 4 compared to quinalizarin; In addition, the inhibition constant (Ki) for compound 4 was lower than Ki for quinalizarin (Table 5).

This phenomenon suggest that these differences could be translated as a higher inhibition of biological activity of kinase- 2 protein (3FL5) in the presence of compound 4 in comparison with quinalizarin.

\section{Conclusions}

In this study, a facile synthesis of new steroid-oxazole-1,2'-[1,3] oxazete] derivative is reported. In addition, the biological activity exerted by this compound on ischemia/reperfusion injury indicated that compound 4 exert a cardioprotective effect by increase the left ventricular pressure via kinase- 2 inhibition. It is important to mention that the experimental results are supported by the experimental data obtained.

Table 5 Termodynamic parameters involved in the interaction of both compound 4 and quinalizarin with $3 F L 5$ protein surface

\begin{tabular}{lllllll}
\hline Compound & $\begin{array}{l}\text { Est. free energy of } \\
\text { binding }(\mathrm{kcal} / \mathrm{mol})\end{array}$ & $\begin{array}{l}\text { Est. inhibition } \\
\text { constant }(\mathrm{Ki}, \mathrm{uM})\end{array}$ & $\begin{array}{l}\mathrm{vdW}+\mathrm{Hbond}+\text { desolv. } \\
\text { energy }(\mathrm{kcal} / \mathrm{mol})\end{array}$ & $\begin{array}{l}\text { Electrostatic } \\
\text { energy }(\mathrm{kcal} / \mathrm{mol})\end{array}$ & $\begin{array}{l}\text { Total intermol. } \\
\text { energy }(\mathrm{kcal} / \mathrm{mol})\end{array}$ & $\begin{array}{l}\text { Interact. surface } \\
\text { Quinalizarin }\end{array}$ \\
\hline 4 & -6.65 & 13.30 & -6.58 & -0.07 & -6.65 & 595.193 \\
\hline
\end{tabular}

The values were determinate using the DockingServer software 
Acknowledgements The authors extend their sincere thanks to Dr. Cindy Rossina Saravia, Rector of the Autonomous University of Campeche for their support in carrying out this study.

\section{Compliance with ethical standards}

Conflict of interest On behalf of all authors, the corresponding author states that there is no conflict of interest.

\section{References}

1. Anderson J, Morrow D (2017) Acute myocardial infarction. N Engl J Med 376:2053-2064. https://doi.org/10.1056/NEJMr a1606915

2. Van't Hof A, Liem A, de Boer M, Zijlstra F, Zwolle (1997) Clinical value of 12-lead electrocardiogram after successful reperfusion therapy for acute myocardial infarction. Lancet 350:615-619. https://doi.org/10.1016/S0140-6736(96),07120-6

3. Granger D (1989) Role of xanthine oxidase and granulocytes in ischemia-reperfusion injury. J Crit Care 4:225

4. Figueroa-Valverde L, Hau-Heredia L, García-Cervera E, PoolGómez E, López-Ramos M, Isabel V, Rosas-Nexticapa M (2017) Activity exerted by a naphthalene-oxirane derivative on the ischemia/reperfusion injury. Biomed Res 28:16-22

5. Armstrong S (2004) Protein kinase activation and myocardial ischemia/reperfusion injury. Cardiovasc Res 61:427-436. https ://doi.org/10.1016/j.cardiores.2003.09.031

6. Bae U, Do-Yang J, Ka S, Koo J, Woo S, Lee Y, Lee S (2014) SPA0355 attenuates ischemia/reperfusion-induced liver injury in mice. Exp Mol Med 46:1-8

7. Maulik N, Watanabe M, Zu Y, Huang C, Cordis G, Schley J, Das D (1996) Ischemic preconditioning triggers the activation of MAP kinases and MAPKAP kinase 2 in rat hearts. FEBS Lett 396:233237. https://doi.org/10.1016/0014-5793(96)01109-X

8. Kim S, Baines C, Critz S, Pelech S, Katz S, Downey J, Cohen M (1999) Ischemia induced activation of heat shock protein 27 kinases and casein kinase 2 in the preconditioned rabbit heart. Biochem Cell Biol 77:559-567. https://doi.org/10.1139/099-065

9. Schulz R, Cohen M, Behrends M, Downey J, Heusch G (2001) Signal transduction of ischemic preconditioning. Cardiovasc Res 52:181-198. https://doi.org/10.1016/S0008-6363(01),00384-4

10. Klotz I (1973) Physicochemical aspects of drug-protein interactions: a general perspective. Ann NY Acad Sci 226:18-35. https ://doi.org/10.1111/j.1749-6632.1973.tb20465.x

11. Reed G, Rossi J, Cannon C (2017) Acute myocardial infarction. Lancet 389:197-210. https://doi.org/10.1016/S0140 $-6736(16), 30677-8$

12. Carmichael D, Geahlen R, Allen S, Krebs E (1982) Type II regulatory subunit of CAMP-dependent protein kinase. Phosphorylation by casein kinase II at a site that is also phosphorylated in vivo. J Biol Chem 257:10440-10445

13. Valen $G$ (2006) Signal transduction through nuclear factor kappa $B$ in ischemia-reperfusion and heart failure. Basic Res Cardiol 99(1):1-7

14. Singh N, Ramji D (2008) Protein kinase CK2, An important regulator of the inflammatory response? J Mol Med 86:887

15. Stephanou A, Scarabelli T, Brar B, Nakanishi Y, Matsumura M, Knight R, Latchman D (2001) Induction of apoptosis and Fas receptor/Fas ligand expression by ischemia/reperfusion in cardiac myocytes requires serine 727 of the STAT- 1 transcription factor but not tyrosine 701. J Biol Chem 276:8340-28347. https ://doi.org/10.1074/jbc.M101177200
16. Das S, Cordis G, Maulik N, Das D (2005) Pharmacological preconditioning with resveratrol: role of $\mathrm{CREB}$-dependent $\mathrm{Bcl}-2$ signaling via adenosine $\mathrm{A} 3$ receptor activation. Am J Physiol Heart Circ Physiol 2881:H328-H335. https://doi.org/10.1152/ ajpheart.00453.2004

17. Li X, Hu H, Wang Y, Xue M, Li X, Cheng W, Yan S (2015) Valsartan upregulates Kir2. 1 in rats suffering from myocardial infarction via casein Kinase 2. Cardiovasc Drugs Ther 29:209-218

18. Litchfield D (2003) Protein kinase CK2: structure, regulation and role in cellular decisions of life and death. Biochem J 369:1-15. https://doi.org/10.1042/bj20021469

19. Ka S, Hwang H, Jang J, Bang I, Bae U, Yu H, Park B (2015) The protein kinase 2 inhibitor tetrabromobenzotriazole protects against renal ischemia reperfusion injury. Sci Rep 5:14816

20. Hathaway G, Lubben T, Traugh J (1980) Inhibition of casein kinase II by heparin. J Biol Chem 255:8038-8041

21. Yim H, Lee Y, Lee C, Lee S (1999) Emodin, an anthraquinone derivative isolated from the rhizomes of Rheum palmatum, selectively inhibits the activity of casein kinase II as a competitive inhibitor. Planta Med 65:9-13. https://doi. org/10.1055/s-1999-13953

22. Cozza G, Mazzorana M, Papinutto E, Bain J, Elliott M, Di-Maira G, Battistutta R (2009) Quinalizarin as a potent, selective and cellpermeable inhibitor of protein kinase CK2. Biochem J 421:387395. https://doi.org/10.1042/BJ20090069

23. Daina A, Michielin O, Zoete V (2017) SwissADME: a free web tool to evaluate pharmacokinetics, drug-likeness and medicinal chemistry friendliness of small molecules. Sci Rep 7(42717):1-13

24. Rageh A, Atia N, Abdel-Rahman H (2017) Lipophilicity estimation of statins as a decisive physicochemical parameter for their hepato-selectivity using reversed-phase thin layer chromatography. J Pharm Biom Anal 142:7-14. https://doi.org/10.1016/j. jpba.2017.04.037

25. Fernandes T, Cunha M, Sakata R, Candido T, Baby A, Tavares M, Parise-Filho R (2017) Synthesis, molecular modeling, and evaluation of novel sulfonylhydrazones as acetylcholinesterase inhibitors for Alzheimer's disease. Arch Der Pharm 350:1700163. https ://doi.org/10.1002/ardp.201700163

26. Kirchweger B, Kratz J, Ladurner A, Grienke U, Langer T, Dirsch V, Rollinger J (2018) In silico workflow for the discovery of natural products activating the $\mathrm{G}$ protein-coupled bile acid receptor 1. Front Chem 6(242):1-14. https://doi.org/10.3389/fchem .2018.00242

27. Figueroa-ValverdeL D-CF, Camacho-Luis A, Garcia-Cervera $E$, Pool-Gomez E, Rosas-Nexticapa M, Sarao-Alvarez A (2013) Activity induced by a progesterone derivative on injury by ischemiareperfusion in an isolated heart model. Afr J Pharm Pharmacol 7:1957-1968. https://doi.org/10.5897/AJPP12.1137

28. Sarabia-Alcocer B, Figueroa-Valverde L, Díaz-Cedillo F, Hau-Heredia L, Rosas-Nexticapa M, García-Cervera E, Zepeda-Acosta B (2014) Activity induced by a naphthalene-prazosin derivative on ischemia/reperfusion injury in rats. Pharmacol Pharm 5:11301142. https://doi.org/10.4236/pp.2014.51212

29. Figueroa-Valverde L, Diaz-Cedillo F, Rosas-Nexticapa M, PoolGomez E, Lopez-Ramos M, Sarabia-Alcocer B (2014) Evaluation of activity exerted by a steroid derivative on injury by ischaemia/reperfusion. Afr J Pharm Pharmacol 8(5):157-167. https:// doi.org/10.5897/AJPP2013.3908

30. Graciotti M, Alam M, Solyakov L, Schmid R, Burley G, Bottrill A, Tobin A (2014) Malaria protein kinase CK2 (PfCK2) shows novel mechanisms of regulation. PLoS ONE 9:1-8. https://doi. org/10.1371/journal.pone.0085391

31. Ramírez-Aportela E, López-Blanco J, Chacón P (2016) FRODOCK 2.0: fast protein-protein docking server. Bioinform 325:23862388. https://doi.org/10.1093/bioinformatics/btw141 
32. Hocht C, Opezzo L, Gorzalczany S, Bramuglia G, Tiara C (1999) Una aproximación cinética y dinámica de metildopa en ratas con coartación aórtica mediante microdiálisis. Rev Arg Cardiol 67:769-773

33. Schulz V, Davoust M, Lemarié M, Lohier J, de Oliveira SJ, Metzner $P$, Brière J (2007) Straightforward stereoselective synthesis of spiro-epoxyoxindoles. Org Lett 9:1745-1748. https://doi. org/10.1021/ol070439x

34. Pérez M, Ramos C, Massi L, Gazzola S, Taglienti C, Yayik N, Molins E, Viayna A, Luque F, Bosch J, Amat M (2017) Enantioselective synthesis of spiro[indolizidine-1,3'-oxindoles]. Org Lett 19:40504053. https://doi.org/10.1021/acs.orglett.7b01818

35. Luo J, Wu B, Chen M, Jiang G, Zhou Y (2014) The concise synthesis of spiro-cyclopropane compounds via the dearomatization of indole derivatives. Org Lett 16:2578-2581. https://doi. org/10.1021/ol500948r

36. Liang J, Chen J, Du F, Zeng X, Li L, Zhang H (2009) Oxidative carbon-carbon bond formation in the synthesis of bioactive spiro $\beta$-lactams. Org Lett 11:2820-2823. https://doi.org/10.1021/ ol901005x

37. Sue D, Kawabata T, Sasamori T, Tokitoh N, Tsubaki K (2010) Synthesis of spiro compounds through tandem oxidative coupling and a framework rearrangement reaction. Org Lett 12:256-258. https://doi.org/10.1021/ol902571p

38. Samajdar S, Becker F, Banik B (2000) Surface-mediated highly efficient regioselective nitration of aromatic compounds by bismuth nitrate. Tetraedron Lett 41:8017-8020. https://doi. org/10.1016/S0040-4039(00),01397-6

39. Canales L, Bandyopadhyay D, Banik B (2011) Bismuth nitrate pentahydrate-induced novel nitration of eugenol. Org Med Chem Lett 1:1-9. https://doi.org/10.1186/2191-2858-1-9

40. Yadav $U$, Mande $H$, Ghalsas $P$ (2012) Nitration of phenols using $\mathrm{Cu}\left(\mathrm{NO}_{3}\right)_{2}$ : green chemistry laboratory experiment. J Chem Educ 89:268-270. https://doi.org/10.1021/ed100957v

41. Matsumoto T, Tokitoh N, Okazaki R (1997) First oxazagermete: synthesis, structure and thermal cycloreversion into a germanone. Chem Commun 16:1553-1554. https://doi. org/10.1039/A703241B
42. Lenn Corkins H, Storace L, Osgood E (1980) A new route to the $4 \mathrm{H}-1,2$-oxazete ring system by the stereospecific oxidation of (Z)-3, 3-dimethyl-1, 1-bis (methylthio)-2-butanone oxime. Tetrahedron Lett 21(21):2025-2028. https://doi.org/10.1016/S0040 $-4039(00), 71476-6$

43. Walter W, Ruback W (1982) 2, 2, 4-Trisubstituted 2H-1, 3-oxazetes-a new type of heterocycles-A reinvestigation. Liebigs Ann Chem 2:231-239. https://doi.org/10.1002/ jlac. 198219820206

44. Meshram R, Baladhye V, Gacche R, Karale B, Gaikar R (2017) Pharmacophore mapping approach for drug target identification: a chemical synthesis and in silico study on novel thiadiazole compounds. J Clin Diag Res 11:KF01-KF08. https://doi.org/10.7860/ JCDR/2017/22761.9925

45. Crivori P, Poggesi I (2006) Computational approaches for predicting CYP-related metabolism properties in the screening of new drugs. Eur J Med Chem 41:795-808. https://doi.org/10.1016/j. ejmech.2006.03.003

46. Figueroa $L$, Rosas $M$, Virginia $M$, Herrera S, Díaz F (2018) New amino-steroid-anthracenone with biological activity against ischemia-reperfusion injury in a Wistar rat model. Open Pharm J 8:10-20. https://doi.org/10.2174/1874143601808010010

47. De-Azevedo J, Walter F, Dias R (2008) Experimental approaches to evaluate the thermodynamics of protein-drug interactions. Curr Drug Target 9:1071-1076. https://doi.org/10.2174/13894 5008786949441

48. LaBute $M$, Zhang $X$, Lenderman J, Bennion B, Wong S, Lightstone $F$ (2014) Adverse drug reaction prediction using scores produced by large-scale drug-protein target docking on highperformance computing machines. PLoS ONE 9:1-13. https:// doi.org/10.1371/journal.pone.0106298

Publisher's Note Springer Nature remains neutral with regard to jurisdictional claims in published maps and institutional affiliations. 